\title{
The emotional influence of media texts due to language redundancy
}

\author{
Yu. V. Litkovych \\ Lutsk National Technical University, Lutsk, Ukraine \\ Corresponding author. Email: litkovych@ukr.net
}

Paper received 14.11.20; Accepted for publication 27.11.20.

\begin{abstract}
https://doi.org/10.31174/SEND-Ph2020-241VIII72-07
\end{abstract}
Abstract. The article focuses on the study of redundant phrases (pleonasms) in media texts discourse within the framework of pragmatic studies. The paper shows the peculiarities of pleonastic phrases in news and advertising. Different functions of advertising which correspond to the functions of pleonastic phrases are distinguished. The pragmatic value of redundant phrases (pleonasms) and their implication, influence on the target audience is studied.

Keywords: redundancy, pleonasms, semantically similar words, pragmatic potential.

Introduction. The influence on the reader or listener in order to convince him/her about correctness of the proposed provisions or to provoke the desired reaction is not made by logical reasoning, but the strength, emotional tension of expression, showing those features that can be most effectively used to achieve this goal [6, p. 99], in other words, the selection of language tools with a powerful suggestive influence - redundant phrases (pleonasms). Pleonasms (pleonastic phrases) are separate words or twocomponent phrases, where redundancy is expressed grammatically and lexically with the help of semantically similar words (HIV-virus - 'human immunodeficiency virus virus', give and bequeath, exactly the same, seldomly, etc.).

The purpose of media discourse is to transfer information from journalists (addressers) who transfer information to readers (addressees). Information consists of facts or truths about the objective, external, referential world. This information text is a public document, in other words, the information provided is brought to the public's attention and is considered to be in line with the topic of interest to the public [7, p. 75]. Pleonastic phrases in media discourse are found in different types of texts, especially in news and advertising.

Review of publications. Redundancy is a complex and multidimensional phenomenon, widely represented both in language and in speech [2]. In linguistic literature there are two types of redundancy distinguished: functional and non-functional [6, p. 100]. The analysis of redundant phrases in modern English discourse has shown that they function in different types of media discourse [7]. Media discourse is an inseparable component of the social life of modern human, the main way of his/her involvement in the events of the world and a mediator in culture formation.

The objective of this article is to complete a theoretical framework of media discourse by revealing the peculiarities and communicational value of pleonastic phrases. It is achieved by fulfilling the following tasks: (i) to define the notion of pleonasm, (ii) to establish the main features of pleonastic phrases; (iii) to systematize pragmatic peculiarities of pleonastic phrases in media texts; (iv) to reveal pragmatic and functional peculiarities of the use of pleonasms in media discourse.

Methods and material. To achieve the aim of the research and accomplish its tasks, a number of general scientific methods, such as analysis and synthesis, induction and deduction, as well as methods of linguistic analysis (contextual, pragmatic and discourse analysis) are used. The research material comprises the fragments, singled out from media discourse, with a specific focus on news and advertising, predominantly selected online from British and American media sources.

Results and discussion. News - are texts that most fully implement one of the main functions of language communication, and one of the main functions of mass communication - informational [3, p. 42]. The textual activity of a journalist to create an information product is the author's desire through the created text to establish communicative interaction with his/her audience in order to implement a specific idea of the message. Reporters, sports commentators, and politicians who give interviews are limited in time, so there are some slips of the tongue in their speech, for example:

(1) It was... it was... a chance coincidence (The CNN).

The pleonastic phrase chance coincidence is used by the addresser to inform the audience that corruption in a football club has only been gossip, and the appearance of false information on the column is a coincidence before important matches.

(2) Today, at Microsoft Ignite we showed new innovations for content collaboration in the modern workplace (The CNN).

Jeff Teper, giving a brief explanation to a CNN News reporter, due to a lack of time, uses the pleonastic phrase new innovations, which is occasional (a nonce word) and indicates the impossibility of expressing one's opinion thoughtfully.

(3) The offender escaped on foot by running (CNN Radio news).

In the example (3), the pleonastic phrase on foot by running is used by the addresser to clarify how the offender escaped.

Pleonastic phrases in the news are used not only as slips of the tongue caused by extralinguistic factors. Their use is also caused by the emotional impact on the audience. Emotionality is a predictable, conscious feature of speech, which appears as a result of the use of language tools that purposefully give speech emotionality and expressiveness, in other words, lead to a deliberately created emotional effect of communication [5, p. 19], for example:

(4) The ocean genome and future prospects for conservation and equity (News Break).

The pleonastic phrase future prospects is used to create the effect of emotional expression. The addresser encour- 
ages the audience to protect the Earth's environment.

(5) The World Health Organization declared COVID19 a global pandemic on Wednesday as the new coronavirus, which was unknown to world health officials just three months ago, has rapidly spread to more than 121,000 people from Asia to the Middle East, Europe and the United States (World Health Organisation).

In the example (5), the pleonastic phrase global pandemic gives speech emotionality and expressiveness, emphasizing that Covid-19 is an extremely serious problem for humanity.

Advertising combines the function of influence as a function of language, realized through a rich arsenal of linguistic and stylistic means, and the function of influence as a function of mass communication, realized through special media technologies inherent in a media [7, p. 42]. According to N. Fairclough, the discourse of the media differs from face-to-face communication because it is characterized by one-sidedness and the absence of feedback. In this type of discourse there is a clear division between producer and consumer, and the power of domination has a hidden nature (hidden relations of power) $[4$, p. 49]. We distinguish the following functions of advertising, which correspond to the functions of pleonastic phrases: informative, argumentative, manipulative, suggestive, reminding and persuasive.

Informative function. English-language commercial advertising texts provide the necessary and sufficient information about the subject of advertising, appealing to the interests of consumers. Typically, such advertising texts operate on new facts without their evaluation, for example:

(6) A bouquet of flowers for an anniversary gift, Valentine's Day, Women's Day, birthday, wedding (Advertisement for a flower shop).

The addresser uses a stylistically neutral pleonasm bouquet of flowers, which clarifies information about the products on sale, namely bouquets of flowers.

Pleonastic phrases in the advertising text are intended to provide information about the new product, to draw the attention of the recipient to the advertised product and convey a persuasive message to target audience.

Argumentative function. Advertising texts provide information that is accompanied by a rational assessment of the content. Influence on the consumer is carried out by logical appeal, in other words, the addresser, using pleonasms, appeals to the logic of the consumer, rationally justifies the reasons for which it is necessary to buy this product.

The main focus in advertising texts is on:

- arguments in favor of the product, for example:

(7) Godfall's cinematic intro is a beautiful and gorgeous lore piece (NewsBreak).

(8) Narrated with verve and wit, this is a mystery in the classic tradition, by turns entertaining and suspenseful, and building to a gripping climax (Book review).

In the example (7) the game Godfall is advertised. The addresser with the help of the pleonastic phrase beautiful and gorgeous convinces the audience to play the game. The example (8) is a book review, where the pleonasm classic tradition adds arguments in favor of June Wright's debut novel "Murder in the telephone exchange".

(9) Furthermore, Apple's marketing has managed to turn a lowly iPad2 accessory into a featured product by branding it as the Smart Cover with desirable benefits and features to produce greater sales (The Huffington Post).

In the example (9) the advertisement showed that earlier iPad2 was not so popular. Now it is worth having due to new benefits. Thus, iPad 2 is positively marked by the pleonastic phrase desirable benefits. Using this phrase, the addresser emphasizes that a new cover for iPad 2 is equipped with all the advantages and improvements.

(10) "He's a wonderfully good singer, so it'll be a little bit of a different side of Tim Minchin we'll see" (BBC).

The pleonastic phrase wonderfully good characterizes Tim Minchin as a good singer, adding the information that he is really talented.

Manipulative function. Advertising texts provide information that is accompanied by an emotional assessment of the message content. Influence on the consumer is carried out through emotional argumentation, in other words, by intensification of the subject of advertisement. Pleonastic phrases help to arouse positive emotions of joy, love, concern for the value and importance of the purchasing, use of goods. Everything mentioned above is the direct purpose of manipulation, for example:

(11) Anyone who knows him knows that he is a very, very smart and clever politician (The New York Times).

The pleonastic phrase smart and clever is used to manipulate the audience and emphasize that Sharpton is a quite intelligent politician, although he is largely an unknown to the political community in Washington.

(12) The Pandora combines a spicy/fruity character from the Belgiain yeast with the bitter, citrusy hop flavors. Not a huge fan typically of hoppy Belgian ales - I don't find that the flavors blend together, but the Pandora is an exception. The hops work well, blending with the peppery spiciness from the yeast (The Weekly Citizen).

The pleonastic phrase blend together is used by the addresser in advertising a product for manipulative purposes. The purpose of manipulation is to change the intentions of the addressee in the right direction for the addresser, even against the interests of the first. Pandora is not an ordinary Belgian pale ale, but hands craft ale where the hops work well, blending with the peppery spiciness from the yeast.

To achieve a longer manipulative effect, the addresser uses pleonastic phrases, because ideas or concepts are better absorbed by his/her audience. Semantic redundancy draws the listener's attention to the phrase and helps to remember the necessary information, in other words, in this way there is a hidden manipulation of people's consciousness in the right direction for the addresser [1], for example:

(13) [...] it's exterior is attractive, however, we have no time to go inside to take a look, but just a few pictures outside, but it's beautiful and gorgeous for the outlook (Tripadvisor).

The phrase beautiful and gorgeous might be used to describe things, actions, people, or ideas too or an expression of approval when someone brings forth a strong point. For advertising purposes, the pleonastic phrase beautiful and gorgeous is used to manipulate the audience: the Cathedral of Saint Helena is described as extremely pleasant to look at.

Manipulative advertising of English discourse projects 
the values of modern developed post-industrial society, namely the lifestyle, strongly associated with selfaffirmation and self-realization [95, p. 9]. Manipulative advertising emphasizes not just the quality of a particular product that distinguishes it from others, but the image with which the product is associated. With the help of image, advertising changes a lesser-known product into a symbol of prestige. This image should become a model for the consumer. The addressee must want to identify with the characters of the advertising text [7]. Pleonastic phrases in advertising are used by the addresser to manipulate and persuade the consumer to buy a particular product.

Suggestive function. The main purpose of suggestive advertising is suggestion, this type of advertising text is aimed at introducing the consumer to a special psychoemotional state to perform certain commands. Functional and semantic type of speech in suggestive advertising is figurative speech.

(14) You can see everything with your own eyes [...]. Lungs fill with fresh air [...]. At that time you listen to your inner feelings. [...]. Everything remains an unsolved mystery (The Los Angeles Times).

In the example (14) by means of suggestion the consumer subconsciously represents the described resort. The advertising text consists of the same type of constructions with pleonastic phrases that create a monotonous rhythm: see everything with your own eyes, inner feelings, unsolved mystery.

The persuasive function acquires special significance at the stage of growth, when the firm needs to inform the consumer about the benefits of the product and creation of demand. Persuasive advertising through the use of pleonastic phrases affects the mental health of the recipient in order to evoke the need to purchase the advertised product or service, for example:

(15) Pizza rustica or pizzagaina is a large Italian pizza pie consisting of a pastry-like crust that goes both on top and on the bottom, and in between the crust it holds ingredients such as salami, ham, prosciutto, eggs, and Italian cheeses such as mozzarella, ricotta, Pecorino Romano, and Parmigiano Reggiano. You're able to pick and choose your toppings [...] (TasteAtlas).

Due to persuasion, advertising distinguishes the product from similar ones and convinces the consumer to buy it. The pleonastic phrases to pick and choose and pizza pie are used to persuade the recipient to visit Italy and taste a large Italian pizza. The peculiarity of the place is that the visitor can choose the pizza filling.

Reminding function. Reminding advertising is intended to recall information or events that were previously encoded and stored in the brain about the product. It is designed for consumers who have long been familiar with the brand of the advertised product. Reminding advertising influences the consumer by designing such an image that all consumers want to imitate it. Reminding is, for example, advertising of large fashion houses: Salvatore Ferragomo, Prada, Guess, Gucci, Giorgio Armani, Dolce \& Gabbana, etc., for example:

(16) Our designers look ahead to the future and encourage new innovations (Prada advertisement).

In this example (15), the pleonastic phrases to look ahead to the future and new innovations have an impact on the consumer, as they remind him/her that Prada thinks about the future and supports the development of innovations in the field of fashion.

Conclusions. Thus, the pragmatic potential of media broadcasting, which is realized through the function of influence, is realized by expressive-evaluative pleonastic phrases that express the language of the media. And emotionally colored information easily crosses the barriers of audience perception, is better remembered and perceived as a clear and familiar option. Pleonastic phrases are found in different types of media texts: news, media analytics, journalism, and advertising. In live broadcasts, when reporters are limited in time, we notice some slips of the tongue - occasional pleonastic phrases. Pleonastic phrases in media analytics give an assessment of the event, in journalism increase the influence of utterances. Pleonastic phrases in advertising are used on the principle of dominance, namely the dominant side presents its point of view as the absolute truth, trying to achieve one goal: as a result of manipulation to force the consumer to accept his/her opinion. The purpose of advertising is to inform and remind the consumer about the product, convince him/her about the truth of advertising, manipulation of consciousness and suggestion to the subconscious of the addressee and intimidation, which is achieved through the effective use of pleonastic phrases.

\section{REFERENCES}

1. Bekhta I.A. Pragmatics of narrative discourse in journalese style. New Philology. Mykolaiv, 2007. P. 71-84. (In Ukrainian: Бехта I. А. Прагматика оповідного дискурсу у газетно-публіцистичному стилі. Новітня філологія. Миколаїв, 2007. C. 71-84).

2. Benczes R. Repetitions, which are not repetitions: The nonredundant nature of tautological compounds. English language and linguistics, 18 (3), 2014. p. 431-447.

3. Dobrosklonskaya T.G. Media linguistics: theory and methods of studying language in the media. Moscow, 2014. 264 p. (In Russian: Добросклонская Т. Г. Медиалингвистика: системный подход к изучению языка СМИ. М., 2014. 264 с.).

4. Fairclough N. Media Discourse. London: Arnold Publishers, 1995. $224 \mathrm{p}$.

5. Gnezdilova Ya.V. Emotionality and emotivity of modern English discourse: Structural, semantic and pragmatic aspects. Thesis for the candidate degree in philological sciences. Speciality 10.02.04 - Germanic languages. Kyiv, 2007. 291 p. (In Ukrainian: Гнезділова Я.В. Емоційність та емотивність

сучасного англомовного дискурсу: структурний, семантичний і прагматичний аспекти. Дисертація на здобуття вченого ступеня кандидата філологічних наук. Спеціальність 10.02.04 - германські мови. Київ, 2007. 291 с.).

6. Litkovych, Yu., Smal, O. \& Yanovets, A. Structural typology of redundancy in English. Lege artis. Language yesterday, today, tomorrow. The journal of University of SS Cyril and Methodius in Trnava. Trnava: University of SS Cyril and Methodius in Trnava, 2020, V (1), June 2020, p. 99-142. ISSN 2453-8035

7. Potapenko, S.I. Orientational space of modern English media discourse (a cognitive analysis). Thesis for a Doctor's degree in philology. Speciality 10.02.04 - Germanic languages. Kyiv. 2007. 480 p. (In Ukrainian: Потапенко C.I. Орієнтаційний простір сучасного англомовного медіа-дискурсу (досвід лінгвокогнітивного аналізу). Дисертація на здобуття вченого ступеня доктора філологічних наук. Спеціальність 10.02.04 - германські мови. Київ. 2007. 480 с.). 